Article

\title{
Toxic Flatworm Egg Plates Serve as a Possible Source of Tetrodotoxin for Pufferfish
}

\author{
Taiki Okabe ${ }^{\dagger}$, Hikaru Oyama $^{\dagger}$, Maho Kashitani, Yuta Ishimaru, Rei Suo, Haruo Sugita and \\ Shiro Itoi * \\ Department of Marine Science and Resources, Nihon University, Fujisawa, Kanagawa 252-0880, Japan \\ * Correspondence: sitoi@nihon-u.ac.jp; Tel./Fax: +81-466-84-3679 \\ + T. Okabe and H. Oyama equally contributed as first authors.
}

Received: 28 June 2019; Accepted: 10 July 2019; Published: 11 July 2019

\begin{abstract}
The pufferfish Takifugu niphobles (at present Takifugu alboplumbeus) possesses highly concentrated tetrodotoxin (TTX), an extremely potent neurotoxin that provides effective protection from predators, at least at the larval stages. However, the source of the toxin has remained unclear. Recently, DNA from the toxic flatworm Planocera multitentaculata was detected in the intestinal contents of juveniles and young of the pufferfish, suggesting that the flatworm contributes to its toxification at various stages of its life. In this study, we describe the behavior of the pufferfish in the intertidal zone that appears to contribute to its toxification before and during its spawning period: pufferfish were found to aggregate and ingest flatworm egg plates by scraping them off the surface of rocks. DNA analysis based on $28 \mathrm{~S}$ rRNA and cytochrome $c$ oxidase subunit I (COI) genes identified the egg plates as those of $P$. multitentaculata. Liquid chromatography with tandem mass spectrometry analysis revealed that the egg plates contain highly concentrated TTX. The feeding behavior of the pufferfish on the flatworm egg plates was also observed in the aquarium. These results suggest that pufferfish feed on the flatworm egg plate, which enables them to acquire toxicity themselves while providing their offspring with the protective shield of TTX.
\end{abstract}

Keywords: egg plates; flatworm; Planocera multitentaculata; pufferfish; tetrodotoxin (TTX)

Key Contribution: Planocera multitentaculata deposit egg plates on intertidal rocks. The egg plates contain highly concentrated TTX. Takifugu alboplumbeus ingest the TTX-laden egg plates, and are thus toxified.

\section{Introduction}

Tetrodotoxin (TTX), also known as pufferfish toxin, is one of the most potent biological toxins. Its mode of action is by inhibiting neurotransmission by means of blocking voltage-gated sodium channels on excitable membranes of muscle and nerve tissues [1,2]. TTX has been found in organisms from extremely diverse taxa, including amphibians (atelopid frog Atelopus spp. [3]; newts [4]), fish (pufferfish Takifugu spp. [5]; goby Yongeichthys criniger [6]), crustaceans [7], cephalopods [8], gastropods [9], bivalves [10,11], flatworms [12-15], ribbonworms [16,17] and marine bacteria [18,19].

Among these TTX-bearing organisms, pufferfish of the genus Takifugu, in particular, have the reputation of possessing the toxin in abundance [5]. It is believed that the TTX accumulates in the pufferfish body via the food chain, beginning with bacteria as the primary producers $[5,20]$. This conclusion has been inferred by means of several studies where pufferfish fed non-toxic diets after hatching in artificial culture environments, turn out to be non-toxic, and furthermore, these cultured non-toxic pufferfish can then be toxified by means of oral administration of TTX [5,20-23]. On the other hand, tracing the toxification via the food webs exclusively to marine bacteria is unlikely to account 
for the amount of TTX in the pufferfish body, as bacteria have been shown to produce rather minute amounts of toxin [24-27], although TTX levels produced by bacterial cultures (as done in these studies) under potentially non-optimum conditions are likely to be significantly less than those synthesized by bacteria in the natural environment. Recently, our lab reported that the pufferfish Takifugu niphobles (at present Takifugu alboplumbeus) feeds on the toxic eggs of another pufferfish T. pardalis, suggesting that $T$. niphobles effectively toxifies itself by ingesting concentrated TTX from the eggs of related species [28]. Nevertheless, it is important to further explore the source of TTX in pufferfish to fully understand its natural history, especially in relation to the source(s) of TTX, to explain its large reserves.

In another paper, our lab recently reported that the pufferfish T. niphobles (at present Takifugu alboplumbeus) effectively toxified itself by feeding on the flatworm P. multitentaculata [29], suggesting that one of the major sources of TTX in pufferfish was planocerid flatworms. In addition, the flatworm $P$. multitentaculata spawns toxic egg plates on rock and stone surfaces in the intertidal zone from spring to early summer $[30,31]$. When we investigated the ecological relationship between them in the intertidal zone to understand further the involvement of P. multitentaculata in the toxification of the pufferfish, we also noticed another interesting behavior of the pufferfish at the spawning sites of the flatworm. In this study, we describe this behavior of the pufferfish as a possible additional strategy for its toxification.

\section{Results and Discussion}

Spawning colonies of the flatworm P. multitentaculata were found in a $100 \mathrm{~m}^{2}$ square region within the intertidal zone in Hayama, Miura Peninsula, Japan (Figure S1). Up to three adult flatworms and six rocks, with 1-10 egg plates per rock, were found within each spawning colony (Figure 1). The number of egg plates appeared to be a function of the rock size, with larger rocks harboring more egg plates. The smallest rock with an egg plate was $300-400 \mathrm{~g}$ and $<100 \mathrm{~mm}$ in size (Figure 2).

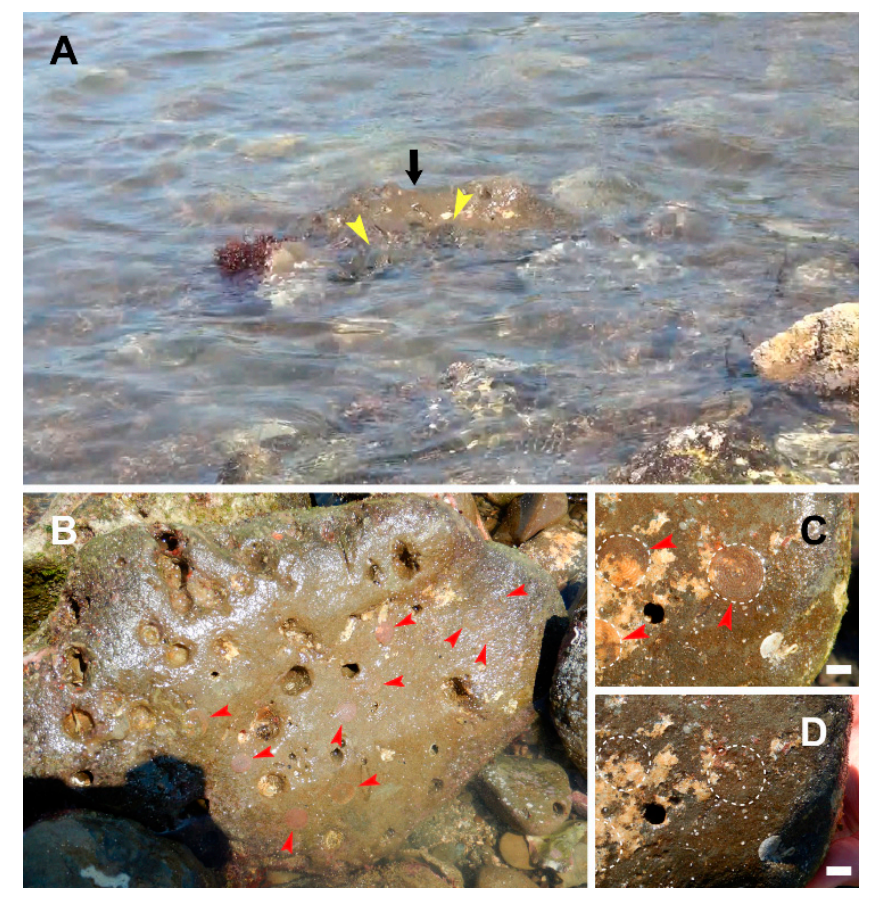

Figure 1. The pufferfish Takifugu niphobles (at present Takifugu alboplumbeus) feeding on the toxic flatworm Planocera multitentaculata egg plates in the wild. Panel A, Multiple pufferfish (yellow arrowheads) feeding on the egg plates on rocks. Panel B, Exposed rock showing multiple flatworm egg plates (red arrowheads) deposited on the surface. Panels $\mathbf{C}$ and D, Rock surface showing the intact egg plates before pufferfish feeding, and bare rock soon after feeding, respectively. Scale bars, $10 \mathrm{~mm}$. The video of the feeding behavior is provided as supplementary data (Video S1). 


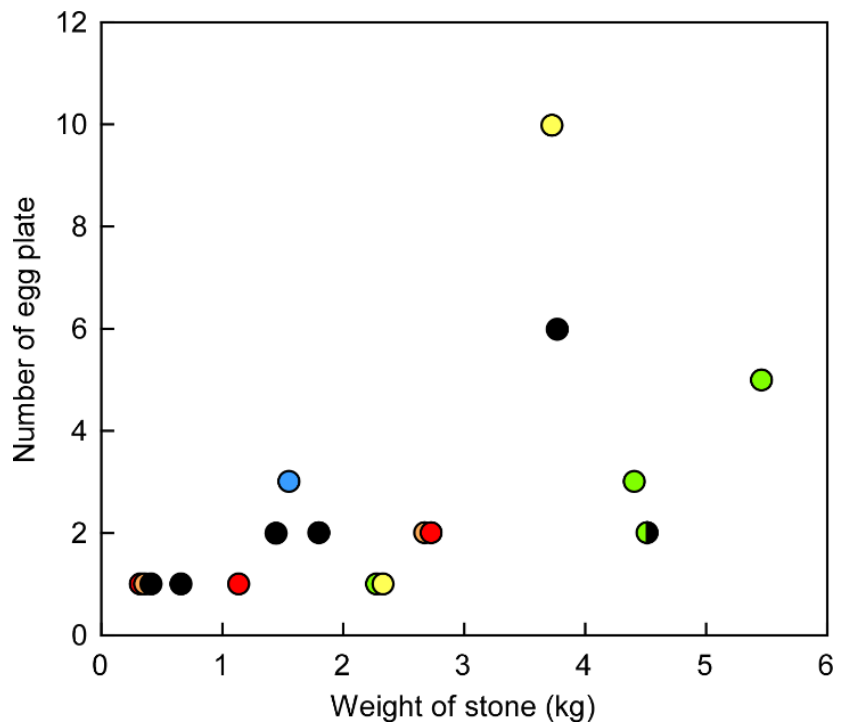

Figure 2. A plot showing the relationship between the weight of the rock and number of the flatworm Planocera multitentaculata egg plates deposited on it. Each color represents rocks collected from a different colony. Red, orange and yellow: 08 May 2019; green, blue and black: 22 May 2019.

We rearranged egg plate-bearing rocks that were obscured so that any egg plate feeding by pufferfish could be observed more easily. We found that several T. alboplumbeus specimens aggregated at the egg plate-bearing rocks during the incoming tide (Figure 1A). The receding tides revealed that the egg plates had been scraped off from the rocks where the pufferfish had aggregated (Figure 1C,D), suggesting that the pufferfish had fed on them.

Any remaining parts of the egg plates were collected and subjected to DNA sequencing and TTX extraction, followed by liquid chromatography with tandem mass spectrometry (LC-MS/MS) analysis. The 28S rRNA (LC489235-LC489236) and cytochrome $c$ oxidase subunit I (COI) gene (LC489237-LC489238) fragment DNA sequences obtained were identical to those of the flatworm $P$. multitentaculata [32]. In addition, multiple reaction monitoring (MRM) patterns of the egg plate extracts were identical to that of standard TTX (Figure 3), and the toxin concentration was $23 \pm 16 \mu \mathrm{g} / \mathrm{g}$, which was highly significantly less than that in egg plates spawned in the laboratory $(9393 \pm 3356 \mu \mathrm{g} / \mathrm{g})$ or in adult specimens $(115 \pm 52 \mu \mathrm{g} / \mathrm{g})(p<0.01$; Table 1$)$. The toxicity of egg plates from the wild was also apparently lower than the values reported in previous studies [30,31]. Since the TTX concentration of the flatworm larvae was equal or more than that of the flatworm egg plate, indicating that the toxin concentration of the egg capsule (jelly-like coat) itself was extremely low [31], our results show that the pufferfish ingested the flatworm embryos within the egg plates, targeting the toxic parts of the egg plates.

Table 1. Toxicity of the flatworm Planocera multitentaculata at the adult and egg stages.

\begin{tabular}{cccccc}
\hline Sample & $\boldsymbol{n}$ & $\begin{array}{c}\text { Body Weight } \\
(\mathbf{g})\end{array}$ & Sample from: & $\begin{array}{c}\text { TTX } \\
\text { Concentration } \\
(\mu \mathrm{g} / \mathrm{g})\end{array}$ & TTX Amount $(\boldsymbol{\mu g})$ \\
\hline Adult & 6 & $4.39 \pm 0.92$ & Wild & $115 \pm 52^{\mathrm{b}}$ & $523 \pm 285$ \\
Egg plate & 3 & N/A & Wild & $23 \pm 16^{\mathrm{a}}$ & N/A \\
Egg plate & 3 & N/A & Aquarium & $9328 \pm 3356^{\mathrm{a}}$ & N/A \\
\hline
\end{tabular}

Remaining fragments of egg plates were collected after feeding by the pufferfish Takifugu niphobles (at present Takifugu alboplumbeus). Data are shown as mean \pm standard deviation. Different superscripts $\left({ }^{\mathrm{a}}\right.$ and $\left.{ }^{\mathrm{b}}\right)$ in TTX column indicate a significant difference among the measured values (Tukey-Kramer post-hoc test, $p<0.01$ ). 

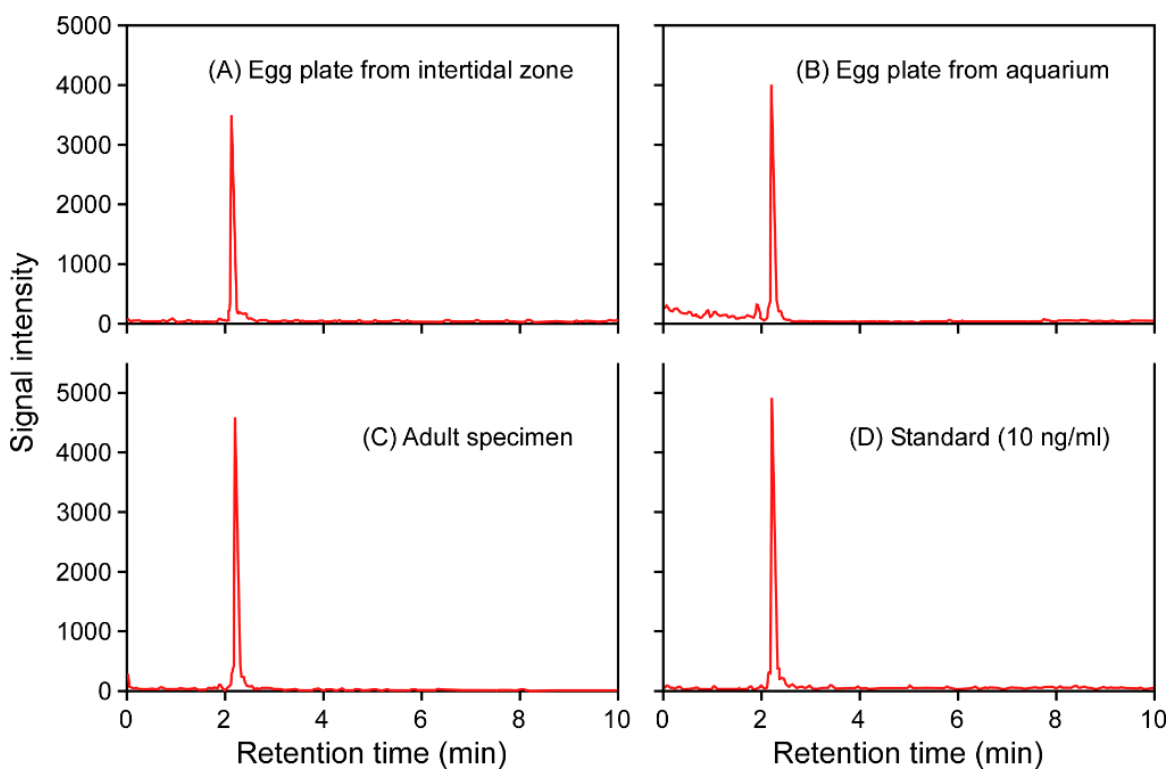

Figure 3. Typical mass chromatograms of the liquid chromatography with tandem mass spectrometry (LC-MS/MS) obtained under multiple reaction monitoring (MRM) mode ( $m / z 320>162)$. MRM patterns of extracts from the flatworm Planocera multitentaculata egg plates spawned in the wild (A), extracts from the flatworm egg plates spawned in the aquarium (B), extracts from the wild adult flatworms (C), and $50 \mathrm{ng} / \mathrm{mL}$ tetrodotoxin (TTX) standard (D).

For the feeding experiment in the laboratory aquarium, adult T. alboplumbeus specimens were fed on the toxic planocerid egg plates deposited on the inside wall of transparent plastic containers (Figure 4). Highly concentrated TTX $(9393 \pm 3356 \mu \mathrm{g} / \mathrm{g})$ was detected from the egg plate samples by LC-MS/MS analysis (Figure 3; Table 1), as in previous reports [30,31]. It is possible that the pufferfish use olfaction in detecting the toxic flatworm egg plates, since pufferfish have been reported to be able to smell TTX [33]. Interestingly, however, the pufferfish in our study tried to scrape the egg plates from the outer wall of the transparent plastic containers even though the egg plates had been deposited on the inner walls, suggesting that they (also) used visual cues to detect the egg plates. Further investigations are needed to understand this behavior. A control was introduced by allowing the pufferfish to feed on dried krill and artificial feed. The pufferfish ingest the toxic egg plates more positively than dried krill or artificial feed.
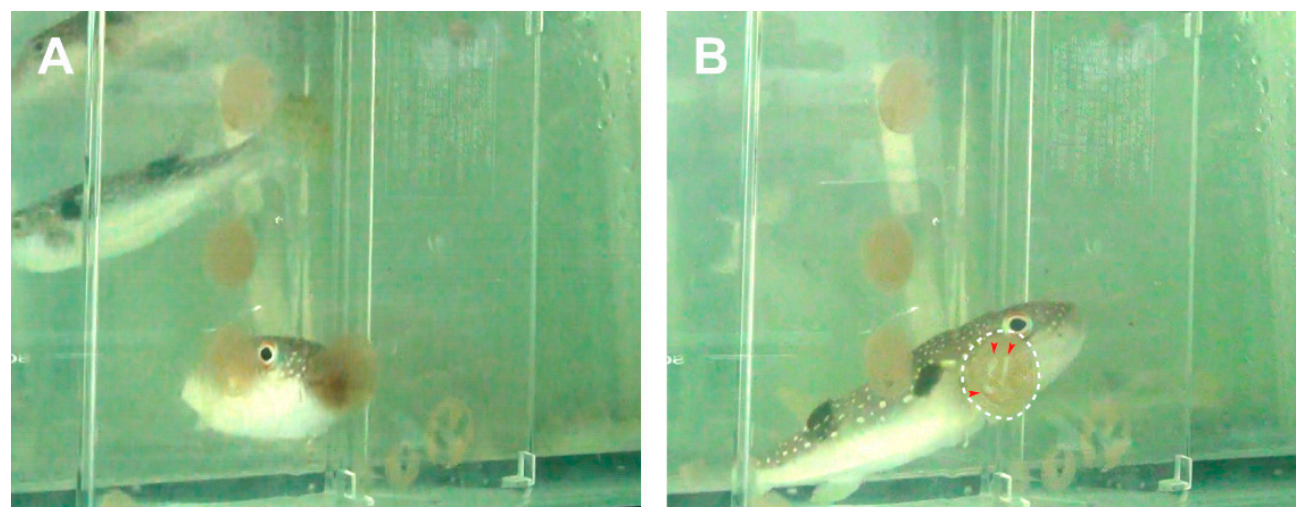

Figure 4. The pufferfish Takifugu niphobles (at present Takifugu alboplumbeus) feeding on the flatworm Planocera multitentaculata egg plates in the aquarium. Panel A, Multiple pufferfish feeding on egg plates on the surface of the plastic container. Panel B, Condition of the egg plate before and after being fed by the pufferfish. Red arrowheads indicate tooth marks made by the pufferfish. The video of the feeding behavior is provided as supplementary data (Video S2). 
Previously, we had reported that T. niphobles (at present Takifugu alboplumbeus) juveniles and adults/young became toxic by feeding on P. multitentaculata larvae and adults, respectively [29]. Our findings in this study now show that the pufferfish also feed on P. multitentaculata egg plates, and thus, the flatworm egg plates appear to be an additional source of TTX. The flatworm egg plates deposited on rock and stone surfaces in the wild are known to contain highly concentrated TTX [30,31]. Our present study suggests that $P$. multitentaculata contributes to the toxification of $T$. alboplumbeus throughout its life, including the egg stage.

Females of pufferfish in the genus Takifugu accumulate TTX in the ovaries, evidently to protect their larvae immediately upon hatching [34,35], although TTX might also be important to the pufferfish as a pheromone, as they appear to use it for aggregation during spawning [36,37]. As shown in Figure 5, P. multitentaculata spawn prior to T. niphobles (at present Takifugu alboplumbeus) in this region [31,37]. It is necessary that the pufferfish ingest TTX efficiently for the survival of the next generation [34,35], and the TTX source appears to be the flatworm and/or its egg plates.

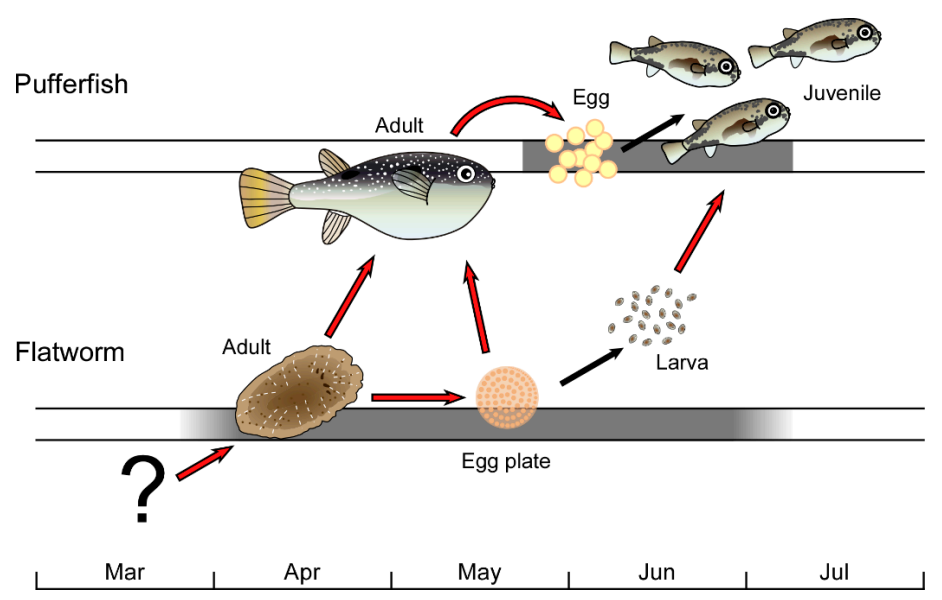

Figure 5. The life histories of the flatworm Planocera multitentaculata and the pufferfish Takifugu niphobles (at present Takifugu alboplumbeus), connected by the TTX present in the flatworm. The pufferfish ingests TTX by feeding on the flatworm egg plates (present study) and adults/young [29]. Red and black arrows indicate transfer of TTX and hatching, respectively. Horizontal gray bars represent the spawning season of the pufferfish (upper) and the toxic flatworm (lower).

Planocera multitentaculata deposit egg plates on unexposed sides of rocks in the intertidal zone [31,38]. These rocks varied in weight from a few hundred grams to a few kilograms. Although the rocks are generally too heavy for the pufferfish to overturn on their own, they are likely to be overturned by the force of the waves in the intertidal zone, and pufferfish risk entering the shallow waters before and during their spawning period to look for exposed P. multitentaculata egg plates. The start of the incoming tide might be the perfect opportunity for the pufferfish to feed on TTX-bearing organisms such as flatworms and ribbonworms or their eggs. On the other hand, the number of TTX-bearing organisms in this region is likely to be too low to account for the amount of TTX in the flatworm body [31]. Further studies are necessary to determine all the sources of TTX that endow the pufferfish with the potent toxicity that it is well known for $[5,20]$.

\section{Conclusions}

In summary, the toxic planocerid flatworm P. multitentaculata spawns toxic egg plates on stones in the intertidal zone from spring to early summer. During this period, the toxic egg plates of the flatworm are fed upon by the pufferfish T. alboplumbeus (as confirmed by us in both the natural environment and glass aquaria). The flatworm spawns prior to the pufferfish in this region. These results suggest that the pufferfish utilize flatworm egg plates as an (additional) source of TTX with which to fortify themselves and the next generation. 


\section{Materials and Methods}

\subsection{Observation of Feeding Behavior in the Natural Environment}

The feeding behavior of T. niphobles (at present Takifugu alboplumbeus) on P. multitentaculata egg plates deposited on rocks in the intertidal zone was observed at the start of the incoming tide (Hayama, Miura Peninsula, Japan; $35^{\circ} 15^{\prime} \mathrm{N}, 139^{\circ} 34^{\prime} \mathrm{E}$; Figure S1). The stones with the flatworm egg plates were positioned such that the egg plates were easily visible. Observations were made on three separate occasions in April/May 2019, and recorded by video camera. The condition of the egg plates on the rocks before and after feeding were noted. Once the tide receded, the remaining egg plates were collected and stored at $-30^{\circ} \mathrm{C}$ for TTX and DNA extraction. The weight of the stones on which the flatworm deposited egg plates was measured by a handy electric balance in the field.

\subsection{Feeding Experiment in the Laboratory}

Takifugu alboplumbeus adults ( $n=9,79-106 \mathrm{~mm}$ standard length, 13.0-32.5 g body weight) were captured and reared for 2 weeks until the feeding experiment in the laboratory aquaria. Planocera multitentaculata adults ( $n=6,3.21-5.73 \mathrm{~g}$ body weight) were also captured and reared for 2 weeks until egg plates were deposited in plastic containers. The feeding experiment was carried out using wild T. alboplumbeus adults and toxic planocerid egg plates, dried krill or artificial feeds as food, in a 50-L glass aquarium with a circulating filtration system. The plastic containers with the flatworm egg plates deposited on them were placed in the aquarium containing the pufferfish, and the feeding behavior was observed and recorded by video camera. After feeding, the remaining egg plates were removed for TTX extraction.

\subsection{PCR Amplification and DNA Sequencing}

Total genomic DNA was extracted from egg plates following Tsunashima et al. [32]. DNA fragments corresponding to partial sequences of the 28S rRNA gene (approx. $1100 \mathrm{bp}$ ) and COI gene (approx. $600 \mathrm{bp}$ ) were amplified by PCR using pairs of primers HRNT-F2 (5'-AGTTC AAGAG TACGT GAAAC C-3') / HRNT-R2 (5'-AACAC CTTTT GTGGT ATCTG ATGA-3') and HRpra2 (5'-AATAA GTATC ATGTA RACTD ATRTC T-3') / HRprb2-2 (5'-GDGGV TTTGG DAATT GAYTA ATACC TT-3'), respectively [32]. PCR amplification and sequencing of the PCR products were conducted following the protocol of our previous report [29]. The flatworm 28S rRNA and COI gene sequences have been submitted to the DDBJ/EMBL/GenBank databases under the accession numbers LC489235-LC489238.

\subsection{LC-MS/MS Analysis}

TTX extraction and LC-MS/MS analysis were done following the method used in a previous study [29]. The calibration curve was generated with 1-100 ng/mL of TTX standard (FUJIFILM Wako Pure Chemicals, Osaka, Osaka, Japan), which showed good linearity and precision $(y=28.7128 x+$ $\left.21.1116, r^{2}=0.9911\right)$. The limit of detection value was calculated at $4.4 \mathrm{ng} / \mathrm{mL}$ for TTX.

\subsection{Statistical Analysis}

Data on TTX concentration from LC-MS/MS analysis were subjected to one-way analysis of variance (ANOVA) followed by the Tukey-Kramer post-hoc test, using StatView ver. 5.0 (SAS Institute Inc., Cary, NC, USA, 1999). A significance level was set at $p<0.01$.

Supplementary Materials: The following are available online at http://www.mdpi.com/2072-6651/11/7/402/s1, Figure S1: Sampling site of the flatworm Planocera multitentaculata egg plates and observation of the pufferfish behavior. Arrow in the map indicates the specific location of the sampling site (the intertidal zone of Hayama, Miura Peninsula, Japan); Video S1: Predation process of the pufferfish Takifugu niphobles (at present Takifugu alboplumbeus) against the flatworm Planocera multitentaculata egg plates in the natural environment; Video S2: Predation process of the pufferfish Takifugu niphobles (at present Takifugu alboplumbeus) against the flatworm Planocera multitentaculata egg plates in the laboratory. 
Author Contributions: T.O., H.O., M.K., R.S. and S.I. collected samples. T.O., H.O., M.K., Y.I. and S.I. performed the LC-MS/MS analysis. S.I. designed the study, supervised the data analysis and interpreted the results. All the authors wrote the first draft of the manuscript, and discussed the results and commented on the manuscript.

Funding: This study was supported in part by the Toyo Suisan Foundation (2019) (to Shiro Itoi), and Japan Society for the Promotion of Science (JSPS) Grant-in-Aid for Scientific Research (B) (15H04552), Grant-in-Aid for Challenging Research (Exploratory) (18K19238) and Grant-in-Aid for Scientific Research (A) (19H00954) (to Shiro Itoi).

Conflicts of Interest: The authors declare that there are no conflicts of interest.

\section{References}

1. Colquhon, D.; Henderson, R.; Ritchie, J.M. The binding of labeled tetrodotoxin to non-myelineated nerve fibres. J. Physiol. 1972, 227, 95-126. [CrossRef] [PubMed]

2. Narahashi, T. Pharmacology of tetrodotoxin. J. Toxicol. Toxin Rev. 2001, 20, 67-84. [CrossRef]

3. Kim, Y.H.; Brown, G.B.; Mosher, H.S.; Fuhrman, F.A. Tetrodotoxin: Occurrence in atelopid frogs of Costa Rica. Science 1975, 189, 151-152. [CrossRef] [PubMed]

4. Mosher, H.S.; Fuhrman, G.J.; Fuhrman, F.A.; Fischer, H.G. Tarichatoxin-tetrodotoxin, a potent neurotoxin. Science 1964, 144, 1100. [CrossRef] [PubMed]

5. Noguchi, T.; Arakawa, O.; Takatani, T. TTX accumulation in pufferfish. Comp. Biochem. Physiol. D 2006, 1, 145-152. [CrossRef] [PubMed]

6. Noguchi, T.; Hashimoto, K. Isolation of tetrodotoxin from a goby Gobius criniger. Toxicon 1973, 11, 305-307. [CrossRef]

7. Noguchi, T.; Uzu, A.; Koyama, K.; Maruyama, J.; Nagashima, Y.; Hashimoto, K. Occurrence of tetrodotoxin as the major toxin in the xanthid crab Atergatis floridus. Nippon Suisan Gakkaishi 1983, 49, 1887-1892. [CrossRef]

8. Sheumack, D.D.; Howden, M.E.; Spence, I.; Quinn, R.J. Maculotoxin: A neurotoxin from the venom glands of the octopus Hapalochlaena maculosa identified as tetrodotoxin. Science 1978, 199, 188-189. [CrossRef]

9. Hwang, D.-F.; Lu, S.C.; Jeng, S.-S. Occurrence of tetrodotoxin in the gastropods Rapana rapiformis and $R$. venosa venosa. Mar. Biol. 1991, 111, 65-69. [CrossRef]

10. McNabb, P.S.; Taylor, D.I.; Ogilvie, S.C.; Wilkinson, L.; Anderson, A.; Hamon, D.; Wood, S.A.; Peake, B.M. First detection of tetrodotoxin in the bivalve Paphies australis by liquid chromatography coupled to triple quadrupole mass spectrometry with and without precolumn reaction. J. AOAC Int. 2014, 97, 325-333. [CrossRef]

11. Katikou, P. Public health risks associated with tetrodotoxin and its analogues in European waters: Recent advances after the EFSA scientific opinion. Toxins 2019, 11, 240. [CrossRef] [PubMed]

12. Miyazawa, K.; Jeon, J.K.; Maruyama, J.; Noguchi, T.; Ito, K.; Hashimoto, K. Occurrence of tetrodotoxin in the flatworm Planocera multitentaculata (Platyhelminthes). Toxicon 1986, 24, 645-650. [CrossRef]

13. Tanu, M.B.; Mahmud, Y.; Arakawa, O.; Takatani, T.; Kajihara, H.; Kawatsu, K.; Hamano, Y.; Asakawa, M.; Miyazawa, K.; Noguchi, T. Immunoenzymatic visualization of tetrodotoxin (TTX) in Cephalothrix species (Nemertea: Anopla: Palaeonemertea: Cephalotrichidae) and Planocera reticulata (Platyhelminthes: Turbellaria: Polycladida: Planoceridae). Toxicon 2004, 41, 515-520. [CrossRef] [PubMed]

14. Ritson-Williams, R.; Yotsu-Yamashita, M.; Paul, V.J. Ecological functions of tetrodotoxin in a deadly polyclad flatworm. Proc. Natl. Acad. Sci. USA 2006, 103, 3176-3179. [CrossRef] [PubMed]

15. Ueda, H.; Itoi, S.; Sugita, H. TTX-bearing planocerid flatworm (Platyhelminthes: Acotylea) in the Ryukyu Islands, Japan. Mar. Drugs 2018, 16, 37. [CrossRef] [PubMed]

16. Miyazawa, K.; Higashiyama, M.; Ito, K.; Noguchi, T.; Arakawa, O.; Shida, Y.; Hashimoto, K. Tetrodotoxin in two species of ribbon worm (Nemertini), Lineus fuscoviridis and Tubulanus punctatus. Toxicon 1988, 26, 867-874. [CrossRef]

17. Asakawa, M.; Ito, K.; Kajihara, H. Highly toxic ribbon worm Cephalothrix simula containing tetrodotoxin in Hiroshima Bay, Hiroshima Prefecture, Japan. Toxins 2013, 5, 376-395. [CrossRef]

18. Noguchi, T.; Hwang, D.F.; Arakawa, O.; Sugita, H.; Deguchi, Y.; Shida, Y.; Hashimoto, K. Vibrio alginolyticus, a tetrodotoxin-producing bacterium, in the intestine of the fish Fugu vermicularis vermicularis. Mar. Biol. 1987, 94, 625-630. [CrossRef]

19. Simidu, U.; Noguchi, T.; Hwang, D.F.; Shida, Y.; Hashimoto, K. Marine bacteria which produce tetrodotoxin. Appl. Environ. Microbiol. 1987, 53, 1714-1715. 
20. Noguchi, T.; Arakawa, O. Tetrodotoxin - distribution and accumulation in aquatic organisms, and cases of human intoxication. Mar. Drugs 2008, 6, 220-242. [CrossRef]

21. Matsui, T.; Hamada, S.; Konosu, S. Difference in accumulation of puffer fish toxin and crystalline tetrodotoxin in the puffer fish, Fugu rubripes rubripes. Bull. Jpn. Soc. Sci. Fish. 1981, 47, 535-537. [CrossRef]

22. Matsui, T.; Sato, H.; Hamada, S.; Shimizu, C. Comparison of toxicity of the cultured and wild puffer fish Fugu niphobles. Bull. Jpn. Soc. Sci. Fish. 1982, 48, 253. [CrossRef]

23. Honda, S.; Arakawa, O.; Takatani, T.; Tachibana, K.; Yagi, M.; Tanigawa, A.; Noguchi, T. Toxification of cultured puffer fish Takifugu rubripes by feeding on tetrodotoxin-containing diet. Nippon Suisan Gakkaishi 2005, 71, 815-820. [CrossRef]

24. Miyazawa, K.; Noguchi, T. Distribution and origin of tetrodotoxin. J. Toxicol. Toxin Rev. 2001, 20, 11-33. [CrossRef]

25. Wu, Z.; Xie, L.; Xia, G.; Zhang, J.; Nie, Y.; Hu, J.; Wang, S.; Zhang, R. A new tetrodotoxin-producing actinomycete, Nocardiopsis dassonvillei, isolated from the ovaries of puffer fish Fugu rubripes. Toxicon 2005, 45, 851-859. [CrossRef] [PubMed]

26. Food Safety Commission of Japan. The liver of the aquacultured Japanese pufferfish (natural toxins): Summary. Food Saf. 2017, 5, 169-170. [CrossRef]

27. Wang, X.J.; Yu, R.C.; Luo, X.; Zhou, M.J.; Lin, X.T. Toxin-screening and identification of bacteria isolated from highly toxic marine gastropod Nassarius semiplicatus. Toxicon 2008, 52, 55-61. [CrossRef] [PubMed]

28. Itoi, S.; Kozaki, A.; Komori, K.; Tsunashima, T.; Noguchi, S.; Kawane, M.; Sugita, H. Toxic Takifugu pardalis eggs found in Takifugu niphobles gut: Implications for TTX accumulation in the pufferfish. Toxicon 2015, 108, 141-146. [CrossRef] [PubMed]

29. Itoi, S.; Ueda, H.; Yamada, R.; Takei, M.; Sato, T.; Oshikiri, S.; Wajima, Y.; Ogata, R.; Oyama, H.; Shitto, T.; et al. Including planocerid flatworms in the diet effectively toxifies the pufferfish, Takifugu niphobles. Sci. Rep. 2018, 8, 12302. [CrossRef] [PubMed]

30. Miyazawa, K.; Jeon, J.K.; Noguchi, T.; Ito, K.; Hashimoto, K. Distribution of tetrodotoxin in the tissues of the flatworm Planocera multitentaculata (Platyhelminthes). Toxicon 1987, 25, 975-980. [CrossRef]

31. Yamada, R.; Tsunashima, T.; Takei, M.; Sato, T.; Wajima, Y.; Kawase, M.; Oshikiri, S.; Kajitani, Y.; Kosoba, K.; Ueda, H.; et al. Seasonal changes in the tetrodotoxin content of the flatworm Planocera multitentaculata. Mar. Drugs 2017, 15, 56. [CrossRef]

32. Tsunashima, T.; Hagiya, M.; Yamada, R.; Koito, T.; Tsuyuki, N.; Izawa, S.; Kosoba, K.; Itoi, S.; Sugita, H. A molecular framework for the taxonomy and systematics of Japanese marine turbellarian flatworms (Platyhelminthes, Polycladida). Aquat. Biol. 2017, 26, 159-167. [CrossRef]

33. Okita, K.; Yamazaki, H.; Sakiyama, K.; Yamane, H.; Niina, S.; Takatani, T.; Arakawa, O.; Sakakura, Y. Puffer smells tetrodotoxin. Ichthyol. Res. 2013, 60, 386-389. [CrossRef]

34. Itoi, S.; Yoshikawa, S.; Asahina, K.; Suzuki, M.; Ishizuka, K.; Takimoto, N.; Mitsuoka, R.; Yokoyama, N.; Detake, A.; Takayanagi, C.; et al. Larval pufferfish protected by maternal tetrodotoxin. Toxicon 2014, 78, 35-40. [CrossRef] [PubMed]

35. Itoi, S.; Suzuki, M.; Asahina, K.; Sawayama, E.; Nishikubo, J.; Oyama, H.; Takei, M.; Shiibashi, N.; Takatani, T.; Arakawa, O.; et al. Role of maternal tetrodotoxin in survival of larval pufferfish. Toxicon 2018, 148, 95-100. [CrossRef] [PubMed]

36. Matsumura, K. Tetrodotoxin as a pheromone. Nature 1995, 378, 563-564. [CrossRef] [PubMed]

37. Itoi, S.; Ishizuka, K.; Mitsuoka, R.; Takimoto, N.; Yokoyama, N.; Detake, A.; Takayanagi, C.; Yoshikawa, S.; Sugita, H. Seasonal changes in the tetrodotoxin content of the pufferfish Takifugu niphobles. Toxicon 2016, 114, 53-58. [CrossRef]

38. Ishida, S. Embryogenesis in marine planarians (Polycladida). In Morpho-Differentiation in Planarians from Biological Basis to Gene Manipulation; Teshirogi, W., Watanabe, K., Eds.; Kyoritsu Shuppan Company: Tokyo, Japan, 1998; pp. 241-258. (In Japanese)

(C) 2019 by the authors. Licensee MDPI, Basel, Switzerland. This article is an open access article distributed under the terms and conditions of the Creative Commons Attribution (CC BY) license (http://creativecommons.org/licenses/by/4.0/). 